is currently exploiting these interesting properties of this simple ligand system in chemical and in vivo studies with $\mathrm{Al}$ and $\mathrm{Ga}$.

Acknowledgment is made to NSERC (Canada) for an operating grant and a University Research Fellowship to C.O. We most gratefully thank Professor J. Trotter for the use of his crystallographic facilities and Professor D. R. McLachlan for preliminary toxicity studies.

Supplementary Material Available: For 2, preparative procedure and tables of final positional and equivalent isotropic thermal parameters, calculated hydrogen parameters, anisotropic thermal parameters, bond lengths, bond angles, intraannular torsion angles, torsion angles, and measured and calculated structure factor amplitudes (26 pages). Ordering information is given on any current masthead page.

\section{Macrocyclic Receptor Molecules for Urea: The Use of Electrophiles in the (Co)complexation of Neutral Molecules}

Veronika M. L. J. Aarts, ${ }^{\dagger}$ Catherina J. van Staveren, $^{\dagger}$

Peter D. J. Grootenhuis, ${ }^{\dagger}$ Johan van Eerden, ${ }^{\dagger}$

Laminus Kruise, ${ }^{\ddagger}$ Sybolt Harkema, ${ }^{\ddagger}$ and

David N. Reinhoudt"

\section{Laboratories of Organic Chemistry and Chemical Physics, Twente University of Technology 7500 AE Enschede. The Netherlands}

Received April 14, 1986

A covalently bound carboxylic group or an electrophilic lithium ion can assist in the complexation of urea by macrocyclic polyethers, provided that the macrocycle is sufficiently large to encapsulate urea.

Although hitherto the work on synthetic macrocyclic polydentate ligands almost exclusively deals with selective complexation of cations, ${ }^{1}$ there is an increasing interest in the binding of neutral guest species. ${ }^{2}$ We have recently proven that such complexes exist not only in the solid state but also in solution. ${ }^{3}$ Although a crystalline 18-crown-6-urea (1:5) complex has been isolated, complexes of crown ethers with urea in aqueous solutions hardly exist $\left(\log K_{\mathrm{s}}<0.1\right) .^{5}$ More stable complexes are formed between protonated urea $\left(\mathrm{UrH}^{+} \mathrm{X}^{-}\right)$and macrocyclic polyethers, ${ }^{6}$ with a coordination as in the corresponding complexes with guanidinium salts. ${ }^{7}$ We are currently studying the complexation of urea with

${ }^{\dagger}$ Laboratory of Organic Chemistry.

'Laboratory of Chemical Physics.

(1) (a) de Jong, F.; Reinhoudt, D. N. Adv. Phys. Org. Chem. 1980, 17, 279-433. (b) Izatt, R. M.; Bradshaw, J. S.; Nielsen, S. A.; Lamb. J. D. Christensen, J. J. Chem. Rev. 1985, 85, 271-339.

(2) (a) van Zon, A.; de Jong, F.; Reinhoudt, D. N.; Torny, G. J.; Onwezen, Y. Recl. Trav. Chim. Pays-Bas 1981, 100, 453-459. (b) Vögtle, F.; Sieger, H.; Muller, W. M. Top Curr Chem 1981, 98, 107-119. (c) Elbasyouny, A.; Briggge, H. J.; von Deuten, K.; Dickel, M.; Knöchel, A.; Koch, K. U.; Kopf, J.; Melzer, D.; Rudolph, G. J. Am. Chem. Soc. 1983, 105, 6568-6577. (d) Vögtle, F; Müller, W. M. J. Inclusion Phenom. 1983, 1, 369-386. (e) Watson, W. H.; Galloy, J.; Grossie, D. A.; Vögtle, F.; Müller, W. M. J. Org. Chem. 1984, 49, 347-353. (f) Vögtle, F.; Muller, W. M.; Watson, W. H. Top. Curr. Chem. 1984, 125, 131-164. (g) Weber, G. J. Inclusion Phenom. 1984, 2, 339-347. (h) Drew, M. G. B.; Nicholson, D. G. Acta Crystallogr.. Sect.
C 1985, 41, 1358-1360. (i) Weber, E.; Josel, H.-P.; Puff, H.; Franken, S. J. Org. Chem. 1985, 50, 3125-3132.

(3) (a) de Boer, J. A. A.; Reinhoudt, D. N.; Harkema, S.; van Hummel, G. J.; de Jong, F. J. Am. Chem. Soc. 1982, $104,4073-4076$ (b) van Staveren, C. J.; Aarts, V. M. L. J.; Grootenhuis, P. D. J.; van Eerden, J.; Harkema, S.; Reinhoudt, D. N. J. Am. Chem. Soc., in press

(4) Harkema, S.; van Hummel, G. J.; Daasvatn, K.; Reinhoudt, D. N. $J$ Chem. Soc. Chem. Commun. 1981, 368-369.

(5) Zollinger, D. Ph.; Bos, M.; van Veen-Blauw, A. M. W.; van der Linden, W. E. Anal Chim. Acta 1984, 161, 83-90.

(6) Uiterwijk, J. W. H. M.; Harkema, S.; Reinhoudt, D. N.; Daasvatn, K.; den Hertog, H. J., Jr.; Geevers, J. Ancew. Chem. 1982, 94, 462-463.
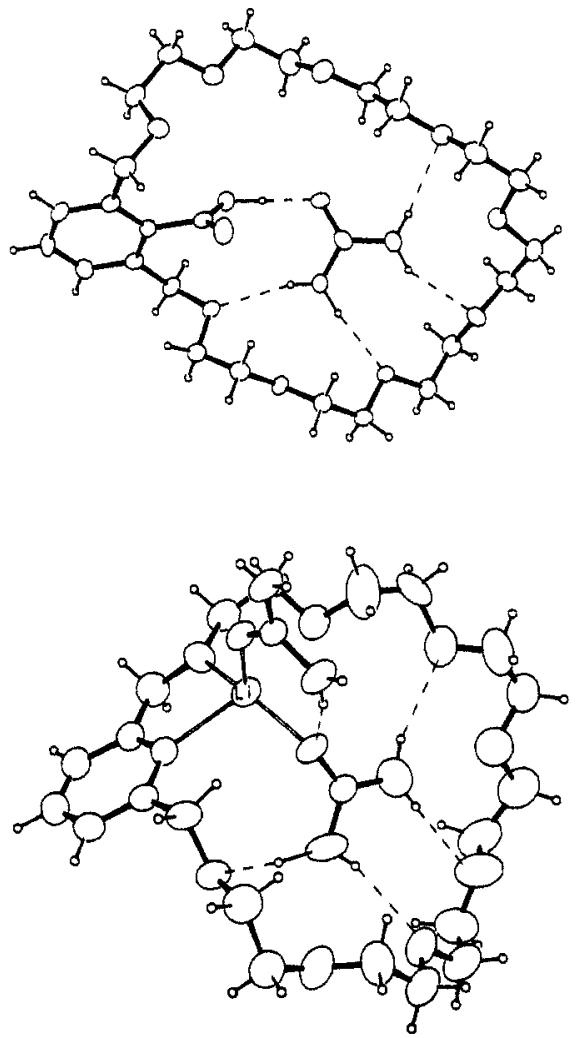

Figure 1. Structures of (a) the 2-carboxyl-1,3-xylyl-30-crown-9-urea complex and (b) the 2,6-pyrido-27-crown-9-bis(urea)--LiClO 4 complex (the perchlorate anion is not shown). Hydrogen bonds indicated by dashed lines.

macrocyclic polyethers containing a covalently linked acidic group, which can protonate the urea molecule, a very weak base ( $\mathrm{p} K_{\mathrm{a}}$ $=0.10, \mathrm{H}_{2} \mathrm{O}, 25.0^{\circ} \mathrm{C}$ ).

2-Carboxyl-1,3-xylyl crown ethers 1a-g were synthesized according to the method described by Cram et al. ${ }^{8}$ Accurate
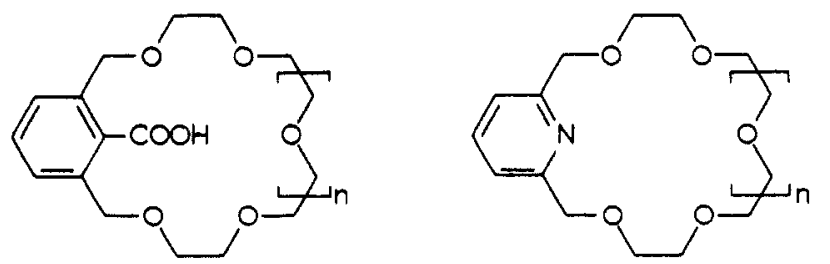

$$
\begin{array}{ll}
\text { 1a, } n=0 & \text { e, } n=4 \\
\text { b, } n=1 & \text { i, } n=5 \\
\text { s, } n=2 & \text { g, } n=6 \\
\text { d, } n=3 &
\end{array}
$$

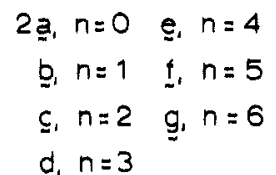

determination of the acidities of the carboxylic group in these crown ethers $(1)\left(\mathrm{p} K_{\mathrm{a}}\right.$ values \pm 0.02$)$ showed that the $\mathrm{p} K_{\mathrm{a}}$ value depends strongly on the ring size of the crown ether. The extremely high $\mathrm{p} K_{\mathrm{a}}$ values of $1 \mathrm{a}$ and $1 \mathrm{~b}$ ( 5.31 and 5.71 , respectively) can be attributed to the stabilization of the acid by intraannular hydrogen bonding to a crown ether oxygen atom. ${ }^{8}$ The relatively high $\mathrm{p} K_{\mathrm{a}}$ values of $1 \mathrm{c}(4.38)$ and $1 \mathrm{~d}(4.06)$ must be due to specific coordination of a water molecule in the cavity, stabilizing the

(7) (a) de Boer, J. A. A.; Uiterwijk, J. W. H. M.; Geevers, J.; Harkema, S. Reinhoudt, D. N. J. Org. Chem. 1983, 48, 4821-4830. (b) van Staveren, C. J.; den Hertog, H. J., Jr.; Reinhoudt, D. N.; Uiterwijk, J. W. H. M.; Kruise, L.; Harkema, S. J. Chem. Soc., Chem. Commun. 1984, 1409-1411

(8) Newcomb, M.; Moore, S. S.; Cram, D. J.J. Am. Chem. Soc. 1977, 99, 6405-6410. 1d: yield 55\% (mp 78-79 $\left.{ }^{\circ} \mathrm{C}\right)$; ' $\mathrm{H} \mathrm{NMR}\left(\mathrm{CDCl}_{3}\right)$ o $3.68(\mathrm{~m}$, $\left.24 \mathrm{H}, \mathrm{CH}_{2} \mathrm{CH}_{2}\right), 4.73\left(\mathrm{~s}, 4 \mathrm{H}, \mathrm{Ar} \mathrm{CH}_{2}\right), 7.29(\mathrm{~s}, 3 \mathrm{H}, \mathrm{Ar} \mathrm{H}), 10.4$ (br s, 1 $\mathrm{H}, \mathrm{OH}$ ). le: yield $58 \%$ (oil); ${ }^{1} \mathrm{H} \mathrm{NMR}\left(\mathrm{CDCl}_{3}\right) \& 3.68\left(\mathrm{~m}, 28 \mathrm{H}, \mathrm{CH}_{2} \mathrm{CH}_{2}\right)$, $4.70(\mathrm{~s}, 4 \mathrm{H}, \mathrm{Ar} \mathrm{CH}), 7.29$ (s, $3 \mathrm{H}, \mathrm{Ar} \mathrm{H}), 8.9$ (br s, $1 \mathrm{H}, \mathrm{OH})$. 1g: yield $36 \%$ (oil); ' $\mathrm{H} \mathrm{NMR}\left(\mathrm{CDCl}_{3}\right) \delta 3.68\left(\mathrm{~m}, 36 \mathrm{H}, \mathrm{CH}_{2} \mathrm{CH}_{2}\right), 4.69(\mathrm{~s}, 4 \mathrm{H}, \mathrm{Ar}$ $\left.\mathrm{CH}_{2}\right), 7.32$ (s, $\left.3 \mathrm{H}, \mathrm{Ar} \mathrm{H}\right), 9.3$ (br s, $\left.1 \mathrm{H}, \mathrm{OH}\right)$. 
carboxylic group. ${ }^{9,10}$ The $\mathrm{p} K_{\mathrm{a}}$ values of $1 \mathrm{e}-\mathrm{g}(3.80,3.94$, and 3.93 , respectively) seem to reach a limiting value and become independent of the ring size. When the $\mathrm{p} K_{\mathrm{a}}$ determinations of 1b, If, and $1 \mathrm{~g}$ were carried out in the presence of a 100-fold excess of urea, we found a small but significant enhancement of the $\mathrm{p} K_{\mathrm{a}}$ values of $1 f$ and $1 \mathrm{~g}$ (both 0.10 ), an effect that hardly exists in the case of $1 \mathrm{~b}\left(\Delta \mathrm{p} K_{\mathrm{a}} \leqslant 0.04\right)$. This increased $\mathrm{p} K_{\mathrm{a}}$ value can be attributed to a specific inclusion of urea, ${ }^{10}$ a proposed complexation which is supported by the isolation of a crystalline 1f-urea (1:1) complex. ${ }^{11}$ The $X$-ray analysis of the 1f-urea complex ${ }^{12}$ (Figure 1) shows that the proton of the carboxylic group is coordinated to the urea oxygen atom via a short hydrogen bond (O...O distance $2.54 \AA, \mathrm{O}-\mathrm{H} \cdots \mathrm{O}$ angle $167^{\circ}$ ). The total encapsulation of urea results in a complex with an apolar exterior, a property that allows for the solubilization of urea in an apolar solvent. A $0.10 \mathrm{M}$ solution of $1 \mathrm{f}$ in $\mathrm{CDCl}_{3}$ solubilized $0.05 \mathrm{M}$ urea $\left(25^{\circ} \mathrm{C}, 17 \mathrm{~h}\right)$. In the absence of $1 \mathrm{f}$ no urea could be dissolved in $\mathrm{CDCl}_{3}$. These results prove that the electrophilic moiety in crown ethers 1 can assist in the complexation of a neutral molecule, and, therefore, we assumed that other electrophiles should also be able to assist in this type of complexation. ${ }^{13}$

When a dilute solution of 2,6-pyrido-27-crown-9 (2e) and an equimolar amount of lithium perchlorate was treated with 1-2 equiv of urea in ethanol, a crystalline complex $(1: 1: 2)$ precipitated. $^{14} \mathrm{X}$-ray structure analysis (Figure 1$)^{15}$ revealed that one of the urea molecules is encapsulated in the crown ether cavity (N...O distances in hydrogen bonds $2.99-3.17 \AA$ ) in a similar way as in the 1f-urea complex with the $\mathrm{Li}^{+}$cation replacing the hydrogen atom of the carboxylic group as a coordinating electrophile (Li ...O distance $1.90 \AA, \mathrm{Li} \cdots \mathrm{N}$ distance $2.20 \AA$ ). The tetrahedral coordination of the lithium cation is completed by a crown ether oxygen and the oxygen atom of a second urea molecule. These $\mathrm{Li}$...O distances (1.98 and $1.95 \AA$ ) are in agreement with values reported for other 4 -fold coordinated $\mathrm{Li}^{+}$ complexes. ${ }^{16}$

From these results we conclude that electrophiles such as $\mathrm{Li}^{+}$ or $\mathrm{H}^{+}$can be vital bridging species in the cocomplexation of neutral guests by crown ethers.

Acknowledgment. These investigations were supported in part by the Netherlands Technology Foundation (S.T.W.) and by the

(9) $1 \mathrm{~d} \cdot \mathrm{H}_{2} \mathrm{O}$ complex $(1: 1)$ was obtained from a methanol/water solution (mp 65-67 ${ }^{\circ} \mathrm{C}$ ); X-ray analysis shows an encapsulated complex in which three hydrogen bonds are formed between the host and the guest molecule. To be published.

(10) Grootenhuis, P. D. J.; Uiterwijk, J. W. H. M.; Reinhoudt, D. N.; van Staveren, C. J.; Sudhölter, E. J. R.; Bos, M.; van Eerden, J.; Klooster, W. T.; Staveren, C. J.; Sudhölter, E. J. R.; Bos, M.; van Eerden, J.; Klooster,
Kruise, L.; Harkema, S. J. Am. Chem. Soc. 1986, I08, 780-788.

(11) Yield 88\% (mp 75-78 $\left.{ }^{\circ} \mathrm{C}\right)$; ${ }^{1} \mathrm{H} \mathrm{NMR}\left(\mathrm{CDCl}_{3}\right) \delta 3.65(\mathrm{~m}, 32 \mathrm{H}$, $\left.\mathrm{CH}_{2} \mathrm{CH}_{2}\right), 4.70\left(\mathrm{~s}, 4 \mathrm{H}, \mathrm{Ar} \mathrm{CH} \mathrm{CH}_{2}\right), 5.6\left(\mathrm{br} \mathrm{s}, 4 \mathrm{H}, \mathrm{NH}_{2}\right), 7.26(\mathrm{~s}, 3 \mathrm{H}, \mathrm{Ar} \mathrm{H})$.

(12) $\mathrm{C}_{25} \mathrm{H}_{40} \mathrm{O}_{1} \cdot \mathrm{CH}_{4} \mathrm{~N}_{2} \mathrm{O}$, monoclinic, space group $P 2_{1} / n, a=19.990(2)$ $\AA, b=8.943$ (1) $\AA, c=16.660$ (1) $\AA, \beta=94.54$ (1),$V=2969$ (1) $\AA^{3}, Z$

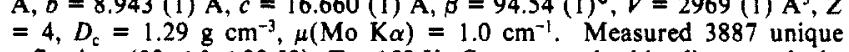
$=4, D_{\mathrm{c}}=1.29 \mathrm{~g} \mathrm{~cm}^{-3}, \mu(\mathrm{Mo} \mathrm{K} \alpha)=1.0 \mathrm{~cm}^{-1}$. Measured 3887 unique
reflections $\left(3^{\circ}<\theta<22.5^{\circ}\right), T=159 \mathrm{~K}$. Structure solved by direct methods. Full-matrix least-squares refinement of 1988 observed reflections $\left(F_{0}^{2}>\right.$ $3 \sigma\left(F_{0}{ }^{2}\right)$ ). Hydrogens from difference Fourier maps; carboxylic and urea hydrogens included in refinement; crown ether hydrogens calculated $(\mathrm{C}-\mathrm{H}$ distance $0.96 \AA)$. Final $R=3.6 \%, R_{w}=3.8 \%, w=4 F_{0}{ }^{2} / \sigma^{2}\left(F_{0}{ }^{2}\right), 382$ variables.

(13) (a) Pascard, C.; Riche, C.; Cesario, M.; Kotzyba-Hibert, F.; Lehn, J.-M. J. Chem. Soc. Chem. Commun. 1982, 557-560. (b) Hosseini, M. W.; Lehn, J.-M. J. Chem. Soc. Chem. Commun, 1985, 1155-1157. (c) Lehn, J.-M. Science (Washington, D.C.) 1985, 227, 849-856.

(14) Yield $80 \%\left(\mathrm{mp} 107-109{ }^{\circ} \mathrm{C}\right) ;{ }^{1} \mathrm{H}$ NMR $\left(\mathrm{CDCl}_{3}\right) \delta 3.2-3.8(\mathrm{~m}, 28$ $\left.\mathrm{H}, \mathrm{CH}_{2} \mathrm{CH}_{2}\right), 4.73\left(\mathrm{~s}, 4 \mathrm{H}, \mathrm{ArCH} \mathrm{CH}_{2}, 7.2-7.9(\mathrm{~m}, 3 \mathrm{H}, \mathrm{Ar} \mathrm{H})\right.$. Anal. Calcd for $\mathrm{C}_{23} \mathrm{H}_{43} \mathrm{ClLiN}_{5} \mathrm{O}_{14}$ : C, 42.11; H, 6.61; N, 10.68. Found: $\mathrm{C}, 42.36 ; \mathrm{H}, 6.59$; N, 10.63 .

(15) $\mathrm{C}_{21} \mathrm{H}_{35} \mathrm{NO}_{8} \cdot 2\left(\mathrm{CH}_{4} \mathrm{~N}_{2} \mathrm{O}\right) \cdot \mathrm{LiClO}_{4}$, triclinic, space group $P \overline{\mathrm{I}}, a=15.687$ (6) $A, b=11.797$ (3) $\AA, c=9.280$ (2) $\AA, \alpha=103.64(2)^{\circ}, \beta=97.40(3)^{\circ}$, $\gamma=99.90(1)^{\circ}, V=1618(2) \AA^{3}, Z=2, D_{\mathrm{c}}=1.35 \mathrm{~g} \mathrm{~cm}^{-3}, \mu($ Mo K $\alpha)=1.8$ $\mathrm{cm}^{-1}$. 5660 Unique reflections $\left(4^{\circ}<\theta<25^{\circ}\right), T=242 \mathrm{~K}$. Solution by direct methods. Refinement of 3875 observed reflections, urea hydrogens included, crown ether hydrogens in calculated positions. Final $R=6.7 \%, R_{w}=9.8 \%$, 450 variables.

(16) (a) Verbist, J.; Meulemans, R.; Piret, P.; van Meerssche, M. Bull. Soc. Chim. Belg. 1970, 79, 391-396. (b) Suleimanov, Kh.; Sergienko, V. S.; Kipkalova, N.; Sulaimankulov, K. Koord. Khim. 1979, 11, 1732-1736. (c) Lebioda, L. Acta Crystallogr. Sect. B 1980, 36, 271-275. (d) Groth, P. Acto Chem. Scand. Ser. A 1982, 36, 109-1 is.
Netherlands Foundation for Chemical Research (S.O.N.) with financial aid from the Netherlands Organization for the Advancement of Pure Research (Z.W.O.).

Supplementary Material Available: Tables containing listings of positional and thermal parameters of the two structures (12 pages). Ordering information is given on any current masthead page.

\section{Barrier to Reductive Elimination of Hydrogen from Dihydridobis(trimethylphosphine)platinum(II)}

Diane L. Packett and William C. Trogler*

Department of Chemistry, D-006 University of California at San Diego La Jolla, California 92093

Received March 31, 1986

Oxidative addition and reductive elimination of $\mathrm{H}-\mathrm{H}, \mathrm{C}-\mathrm{H}$, and $\mathrm{C}-\mathrm{C}$ bonds occur in many catalytic and synthetic reactions. ${ }^{1-4}$ Mechanistic studies of the reductive elimination of carbon-hydrogen $^{5-7}$ and carbon-carbon ${ }^{8-12}$ bonds have been reported for several systems. Intermolecular reductive elimination ${ }^{11}$ can hamper the study of these reactions on a single metal center.

The intramolecular reductive elimination of molecular hydrogen from a mononuclear platinum, palladium, or nickel complex has not been well characterized, although elimination of hydrogen from metal clusters has been suggested as a model for the behavior of hydrogen on surfaces. ${ }^{13}$ Several theoretical studies have considered the oxidative addition and reductive elimination of molecular hydrogen from bis(phosphine)platinum(II) species $^{14-17}$ to gain insight into the mechanism of processes that might occur on a platinum surface. These studies suggest reductive elimination proceeds via a "late" transition state that contains an $\eta^{2}$-dihydrogen ligand. Kinetic barriers predicted range between 18 and 42 $\mathrm{kcal} / \mathrm{mol}$. We report here the first experimental investigation of intramolecular, rate-determining reductive elimination of $\mathrm{H}_{2}$ from a mononuclear dihydride complex containing a metal from the nickel triad, a series of metals frequently used as heterogeneous hydrogenation catalysts.

(1) Collman, J. P.; Hegedus, L. S. Principles and Applications of Organotransition Metal Chemistry; University Science Books: Mill Valley, CA, 1980; Chapter 4.

(2) Collman, J. P. Acc. Chem. Res. 1968, 1, 136-143.

(3) Halpern, J. Acc. Chem. Res. 1970, 3, 386-392.

(4) James, B. R. Homogeneous Hydrogenation; Wiley: New York, 1973.

(5) Abis, L.; Sen, A.; Halpern, J. J. Am. Chem. Soc. 1978, 100 , 2915-2916.

(6) (a) Michelin, R. A.; Faglia, S.; Uguagliati, P. Inorg. Chem 1983, 22, 1831-1834. (b) Buchanan, J. M.; Stryker, J. M.; Bergman, R. G. J.Am. Chem. Soc. $1986,108,1537-1550$.

(7) Okrasinski, S. J.; Norton, J. R. J. Am. Chem. Soc 1977, 99, 295-297.

(8) Braterman, P. S.; Cross, R. J.; Young, G. B. L Chem Soc Dalton Trans. 1977, 1892-1897.

(9) Moravskiy, A.; Stille, J. K. J. Am. Chem Soc.1981, 103, 4182-4186.

(10) Gillie, A.; Stille, J. K. J.Am. Chem. Soc. 1980, 102, 4933-4941.

(11) Norton, J. R. Acc. Chem. Res. 1979, 12, 139-145.

(12) Tamaki, A.; Magennis, S. A.; Kochi, J. K. J.Am. Chem Soc 1974 $96,6140-6146$

(13) Bavaro, L. M.; Montangero, P.; Keister, J. B. L Am.Chem Soc. 1983, 105, 4977-4981.

(14) Noell, J. O.; Hay, P. J. J. Am. Chem. Soc. 1982, 104, 4578-4584.

(15) Low, J. J.; Goddard, W. A., III J. Am. Chem Soc 1984, 106 , 6928-6937. Low, J. J.; Goddard, W. A., III Organometallics 1986, 5, $609-622$.

(16) Obara, S.; Kitaura, K.; Morokuma, K. L Am. Chem Soc 1984. 106, $7482-7492$.

(17) Balazs, A. C.; Johnson, K. H.; Whitesides, G. M. Inorg. Chem. 1982, $21,2162-2174$. 